\title{
Convective and non-convective wind gusts in Poland, 2001-2015
}

\author{
Leszek Kolendowicz, Mateusz Taszarek, Bartosz Czernecki \\ Adam Mickiewicz University in Poznań, Institute of Physical Geography and Environmental Planning, Dziegielowa 27, \\ 61-680Poznań,Poland,e-mail: leszko@amu.edu.pl,tornado@amu.edu.pl,nwp@amu.edu.pl
}

\begin{abstract}
The main aim of the article is to present the climatology of the peak wind gust frequency in Poland caused by the impact of both atmospheric circulation and the presence of thunderstorm clouds. Nine meteorological stations for the measurement period of 2001-2015 were taken into account. Only SYNOP reports with a peak wind gust higher or equal to $15 \mathrm{~m} \mathrm{~s}^{-1}$ in thunderstorm and non-thunderstorm days are considered in this study. The results indicate that the highest threat in terms of frequency and strength of peak wind gusts due to convection occurs in July. In winter, thunderstorms are rare, but if they occur, about $80 \%$ of them produce wind gusts exceeding a threshold of $15 \mathrm{~m} \mathrm{~s}^{-1}$. Peak wind gusts in a non-thunderstorm days are the highest and the most frequent in January, and are at a minimum during summer. Comparing both types, peak wind gusts during days with a thunderstorm were on average stronger than those without an involved convection. This indicated that convection was an important factor in enhancing the strength of a wind gust. The highest value in our base was $34 \mathrm{~m} \mathrm{~s}^{-1}$, recorded in Kraków on 8th July 2015 within the occurrence of a severe thunderstorm, while the highest value in a day without a thunderstorm was $33 \mathrm{~m} \mathrm{~s}^{-1}$, recorded in Łódź on $31^{\text {st }}$ January 2002.
\end{abstract}

Keywords: wind gust, thunderstorm, convective, non-convective, severe weather, Poland

Submitted 21 December 2015, revised 5 May 2016, accepted 10 June 2016

\section{Introduction}

Winds attaining considerable speeds are a meteorological element that may constitute a hazard for both the health and life of man and for the economy. Winds with speeds in excess of $17 \mathrm{~m} \mathrm{~s}^{-1}$ are responsible for causing minor damage to buildings, while in winter, when snow cover is present, they bring about snowstorms, which hinder transport and communication. Winds with a speed exceeding $25 \mathrm{~m} \mathrm{~s}^{-1}$ may cause serious damage to buildings and constitute a major hazard to vehicular and air traffic. Finally, intensive damage is brought about by winds with speeds above $33 \mathrm{~m} \mathrm{~s}^{-1}$ (Lorenc 1996, 2012).

Wind is usually defined as »the movement of air caused by the action of the force of the horizontal pressure gradient, which is subject to the Coriolis force, centrifugal force, and friction force (...) (Niedźwiedź 2003). Wind is designated by stating its mean speed (expressed in $\mathrm{ms}^{-1}$, $\mathrm{kmh}^{-1}$, or in knots) and the direction from which it blows (e.g. a westerly wind refers to the movement of air from the west towards the east). Measurements of mean wind speed and direction relate to 10-minute average values calculated on the basis of the period immediately preceding each full hour by an anemometer under standard measurement conditions, i.e. at a height of 10 meters above ground level (Janiszewski 1988; Lorenc 1996; WMO 2010).

With regard to the most frequently cited record-break- ing wind speeds, these are usually related to wind gust values. This is the maximum momentary $(2-3 \mathrm{sec}$.) wind speed, which exceeds the 2-minute mean wind speed by at least $5 \mathrm{~m} \mathrm{~s}^{-1}$ (Janiszewski 1988; WMO 2010). Wind gusts between full hours of observation are marked in meteorological reports using the symbol QNT, which makes it possible to determine the actual maximum wind gusts for each hour. However, this information is very rarely coded in the standard SYNOP reports, which causes a significant part of the highest wind gusts to possibly be missing in official databases.

In Poland, wind gusts are connected with the occurrence of three different generative causes. One of these is cyclonic atmospheric circulation and the accompanying large horizontal pressure gradients, with the specific spatial pressure pattern over Europe. The second generative cause of wind gusts, which occurs in mountainous areas, are disruptions in circulation brought about under the influence of land orography and the occurrence of foehn winds. It should be observed in this regard that specific types of atmospheric circulation are conducive to the occurrence of wind gusts most frequently in the colder half of the year, during the period from the end of October to the middle of March, that the presence of storm clouds usually leads to the occurrence of gusts in the summer period, from May to the beginning of August, and that foehn circulation is responsible for the occurrence of gusts pri- 
marily in the winter period, from November to February inclusive (Ustrnul 1992; Lorenc 2012). The third cause of the occurrence of wind gusts is the presence of thunderstorm clouds, in particular supercells, which generate conditions conducive to the appearance of squalls and whirlwinds. With the use of manual observational data, the studies of Bielec-Bąkowska (2003), Kolendowicz (2006) and Czernecki et al. (2016) estimated on a long-term basis that an average of 23-24 days with thunderstorms occur in Poland in a particular location. Taszarek et al. (2015), using cloud-to-ground lightning data derived from the PERUN lightning detection network, assessed for Poland an annual average of 151 days with thunderstorms appearing anywhere in Poland. Given such a frequent occurrence of thunderstorms in Poland, the threat of severe wind gusts due to convection may be significant.

For the area of Poland, what is most relevant is the complex analysis of the severe wind gust genesis performed by Lorenc (1996, 2012), who pointed out that circulation patterns are responsible for severe wind gusts during autumn and winter seasons, while convective-related wind gusts were most frequent from May to September. Another study, by Żurański and Jaśpińska (1996), performed a directional analysis of extreme wind speeds in Poland with the use of 23 meteorological stations. However, there are no studies in Poland that consider severe wind gusts distinguished as non-convective and with the presence of a deep moist convection.

Keeping the aforementioned in mind, the objective of the article is to present a climatological analysis of the peak wind gust frequency in Poland caused by the impact of both atmospheric circulation and the presence of thunderstorm clouds, without taking into consideration mountainous areas and the influence exerted thereby on the wind field.

\section{Data and methodology}

In order to obtain the statistics of convective and nonconvective wind gusts, it was necessary to identify the presence of the convection and the strength of the wind gust. Thus, two different data sources were used. Firstly, manual observations of thunderstorms were taken from SYNOP reports derived from the NOAA National Climatic Data Center (NCDC) daily summaries for the period 2001.01.01-2015.12.20. Secondly, reports of the wind gusts were obtained from SYNOP hourly wind gust reports derived for the same period. Both datasets were considered to maintain the continuity of the spatial and temporal measurements in the whole analysed period. However, it needs to be highlighted that the maximum daily wind gusts are based on the individual SYNOP reports issued on an hourly basis. This means that wind gusts represent only the last 10 minutes before the report is issued (Janiszewski 1988). Therefore, if a related wind gust was reported up to 50 minutes after a SYNOP report was issued, it was not included in the database.

In total, we considered in our analysis 9 meteorological stations evenly distributed throughout the country (Fig. 1): Warszawa (WMO code 12375), Poznań (12330), Łódź (12465), Wrocław (12424), Kraków (12566), Rzeszów (12580), Łeba (12120), Szczecin (12205), Suwałki (12195). Stations were selected on the basis of results obtained by Czernecki et al. (2016) who, with the use of lightning data, assessed the quality of the manual thunderstorm observations at these stations. We used the stations that had the highest Critical Success Index (CSI) values (see Czernecki et al. 2016 for further details). We also took into account the metadata described by Lorenc (1996, 2012) with anemological condition measurements, such as anemometer heights, obstacles and roughness class in the vicinity of each of analysed station and decided to pick only stations with similar measurement conditions.

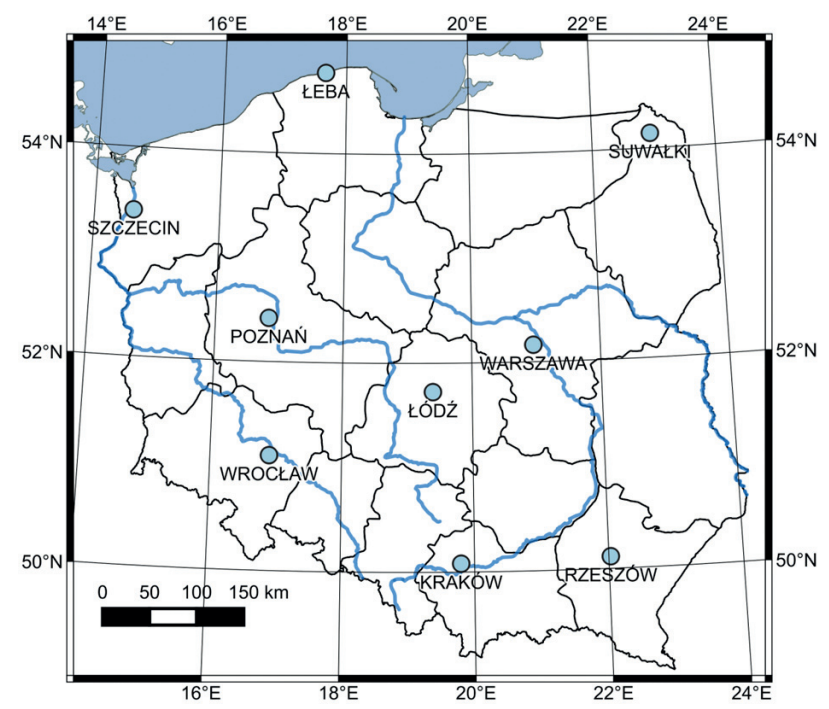

Fig. 1. Location of the meteorological stations used in the study

Since the GTS-based (Global Telecommunication System) archives of weather data (like those published e.g. on most popular websites) contain individual and rare erroneous extreme wind gust records (e.g. cases of $>200 \mathrm{~km} \mathrm{~h}^{-1}$ wind gust), quality control was necessary to obtain reliable results. In the case of each suspicious extreme wind gust record, we considered lightning, radar, satellite, reanalysis and surface observational data within the day of interest. Where there was a lack of indication of a probable severe thunderstorm capable of producing a damaging wind gust, we excluded such cases from further analysis.

For the statistical purposes of our study, we introduced specific wind gust classes. We divided the occurrences into 
wind gusts extending from 15 to $20 \mathrm{~m} \mathrm{~s}^{-1}$ (" 0 " class), 20 to $25 \mathrm{~ms}^{-1}$ ("1" class), 25 to $32 \mathrm{~m} \mathrm{~s}^{-1}$ (" 2 " class), and higher than $32 \mathrm{~m} \mathrm{~s}^{-1}$ (" 3 " class). We based our assumptions on the warning scale used by the Government Centre for Security (in Polish Rządowe Centrum Bezpieczeństwa) that is commonly used by the Institute of Meteorology and Water Management - National Research Institute (IMGW-PIB) in operational forecasting (Table 1). In addition, we added the " 0 " class to this classification to also indicate weaker wind gusts, but those no lower than $15 \mathrm{~m} \mathrm{~s}^{-1}\left(54 \mathrm{~km} \mathrm{~h}^{-1}\right)$.

In order to compare the obtained results with nonthunderstorm wind gusts, we collected and also included in the analysis all available and quality-controlled SYNOP reports with wind gusts exceeding a $15 \mathrm{~m} \mathrm{~s}^{-1}$ threshold and performed an analysis in a monthly time scale.

Table 1. Government Security Centre level threats used for the wind

\begin{tabular}{|c|c|c|c|c|}
\hline \multicolumn{3}{|c|}{ Threat level } & \multicolumn{2}{c|}{ Criteria } \\
\hline 1 & 2 & 3 & 10-min average wind speed & peak wind gust \\
\hline $\mathrm{X}$ & & & $15-20 \mathrm{~m} \mathrm{~s}^{-1}$ & $20-25 \mathrm{~m} \mathrm{~s}^{-1}$ \\
\hline & $\mathrm{X}$ & & $20-5 \mathrm{~m} \mathrm{~s}^{-1}$ & $25-32 \mathrm{~m} \mathrm{~s}^{-1}$ \\
\hline & & $\mathrm{X}$ & $>25 \mathrm{~m} \mathrm{~s}^{-1}$ & $>32 \mathrm{~ms}^{-1}$ \\
\hline
\end{tabular}

\section{Results}

In total, our database consisted of 102816 observations and 3335 of them included of information indicating the presence of thunderstorms. Among them, around 12,4\% (413 cases) were accompanied by wind gusts stronger or equal to $15 \mathrm{~m} \mathrm{~s}^{-1}$. Around $9,1 \%$ of the thunderstorm days (305 reports) corresponded to wind gusts with a strength between 15 and $20 \mathrm{~m} \mathrm{~s}^{-1}$, and 2,5\% (85 reports) to wind gusts of between 20 and $25 \mathrm{~m} \mathrm{~s}^{-1}$. Only a small fraction, around $0,6 \%$ (21 reports), were associated with wind gusts of between 25 and $32 \mathrm{~m} \mathrm{~s}^{-1}$, while only 2 exceeded the $32 \mathrm{~m} \mathrm{~s}^{-1}$ threshold (" 3 " class). Reports of wind gusts exceeding $15 \mathrm{~m} \mathrm{~s}^{-1}$ but not associated with thunderstorm days amounted to 3480 reports in total. Among them, 82,5\% (2871 cases) were associated with a wind gust strength of between 15 and $20 \mathrm{~m} \mathrm{~s}^{-1}$. Around 14,5\% (505 reports) corresponded to the $20-25 \mathrm{~m} \mathrm{~s}^{-1}$ class while $2,9 \%$ (100 cases) to $25-32 \mathrm{~m} \mathrm{~s}^{-1}$. In only 4 situations, meteorological stations measured a wind gust not associated with a thunderstorm stronger than $32 \mathrm{~m} \mathrm{~s}^{-1}$.

In this section we will present the results in an average annual number of days per a meteorological station. Therefore, the obtained results do not correspond to the entire area of the country, but to a particular location.

Analysis of monthly variability of occurrence of all peak wind gusts stronger than $15 \mathrm{~m} \mathrm{~s}^{-1}$ (Fig. 2) associated with a thunderstorm (convective) and not associated with a thunderstorm (non-convective) partially confirmed the previous results obtained by Lorenc (1996, 2012). Among convective wind gusts, the highest frequency falls in July. The annual distribution of the monthly values of convective wind gusts corresponded well to the main thunderstorm season, which extends from May to September (Kolendowicz 2006; Taszarek et al. 2015). During winter months, the occurrence of convective peak wind gusts was marginal, most likely due to the low frequency of thermodynamic instability. Contrary to this, non-convective wind gusts were the most frequent during winter months, and this was related mainly to atmospheric circulation issues. The lowest frequency fell in summer months, but still posed a more common threat than the convective type. Within the $15 \mathrm{~m} \mathrm{~s}^{-1}$ threshold, this was not consistent with the findings of Lorenc (2012), who stated that convectivetype wind phenomena dominate during the warm season.

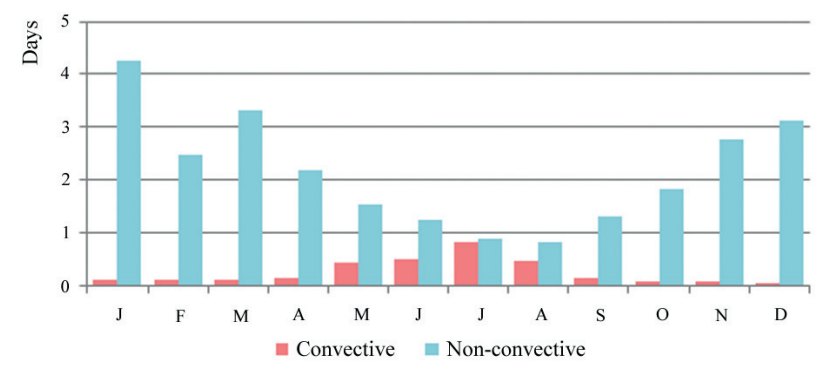

Fig. 2. Average annual number of days with convective and nonconvective peak wind gusts stronger than $15 \mathrm{~m} \mathrm{~s}^{-1}$

On the other hand, if we take into consideration the results in particular wind strength classes, it can be seen that together with the increasing strength of the wind, the convective type prevails in the summer months. In the $15-20 \mathrm{~m} \mathrm{~s}^{-1}$ class, the non-convective type still dominated (Fig. 3), but in the 20-25 $\mathrm{m} \mathrm{s}^{-1}$ class, the convective type posed a higher threat in July and August (Fig. 4). Although the non-convective type in both intervals was the most frequent during the winter months (especially in January and December; Fig. 4), the difference between summer and winter dropped. This indicated that thunderstorms capable of producing severe wind gusts may occur throughout the entire year and are not only restricted to the summer convective thunderstorms. Although thermodynamic instability is lower in autumn, winter and spring months, the occurrence of convective-related atmospheric instability creates more favourable conditions for increasing wind gusts that pose a higher possibility of becoming more severe.

In the second class (Fig. 5), in which the peak wind gusts exceeded $25 \mathrm{~ms}^{-1}$ (a value that is adopted by most 


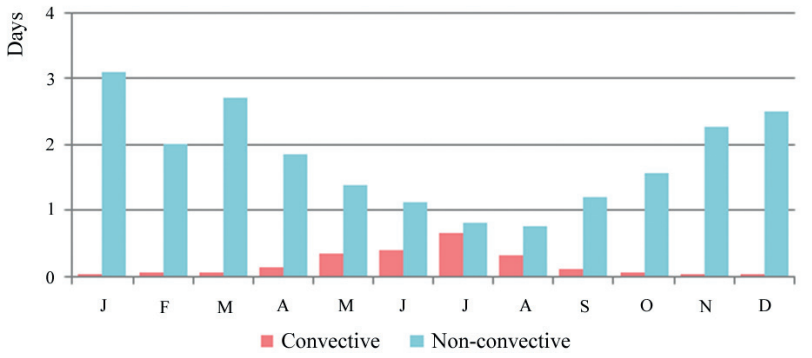

Fig. 3. Average annual number of days with convective and nonconvective peak wind gusts between 15 and $20 \mathrm{~m} / \mathrm{s}$

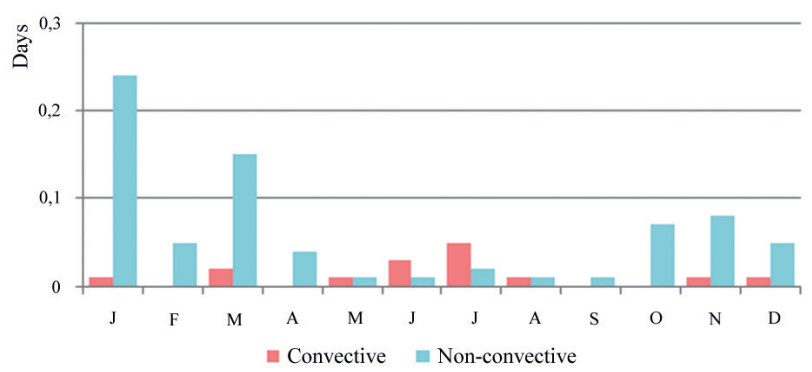

Fig. 5. Average annual number of days with convective and nonconvective peak wind gusts between 25 and $32 \mathrm{~m} \mathrm{~s}^{-1}$

international databases as a damaging wind gust, e.g. the European Severe Weather Database; Dotzek 2009), the occurrence of non-convective wind gusts during the summer season was marginal, but January was still the month with the highest severe wind threat. The convective type peaked again in June and July. We do not provide a figure with peak wind gusts exceeding $32 \mathrm{~ms}^{-1}$ because our database consisted of only 6 such cases. Two such cases, related to the convective type, occurred in July while the non-convective type was found in three cases in January and one case in December.

The comparison of convective and non-convective wind gusts made by considering average values of all peak gusts exceeding or equaling $15 \mathrm{~m} \mathrm{~s}^{-1}$ is presented in Fig. 6 . As the chart shows, the average wind speed of the convective type was higher than the non-convective type in each month. This suggests that convective-related mechanisms are on average capable of producing stronger wind gusts than conditions without convection involved. Presumably, the presence of updrafts and downdrafts in a convective cloud helps to bring the airflow to the ground from higher elevations in a more efficient way than when they are not present. In addition, convection can also generate severe wind gusts through the evaporative cooling of the descending air (microburst) and by organizing it into linear features (bowing lines, derecho).

In total, the highest wind speeds of peak gusts were observed during winter, when the atmospheric airflow resulting from the circulation (stronger horizontal pressure and thermal gradients, and thus thermal wind) was higher. Peak values of a convective type were observed in Decem-

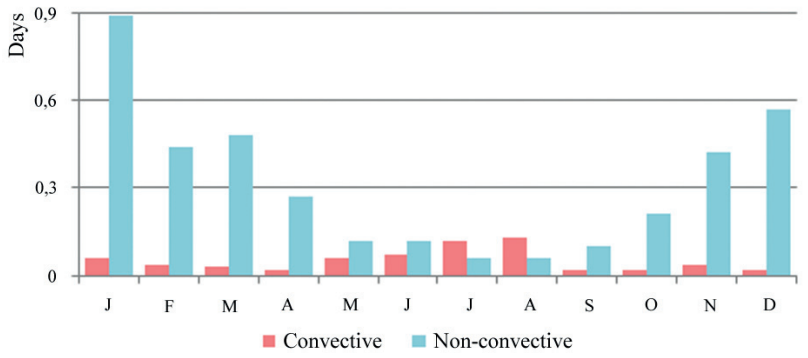

Fig. 4. Average annual number of days with convective and non-convective peak wind gusts between 20 and $25 \mathrm{~m} / \mathrm{s}$

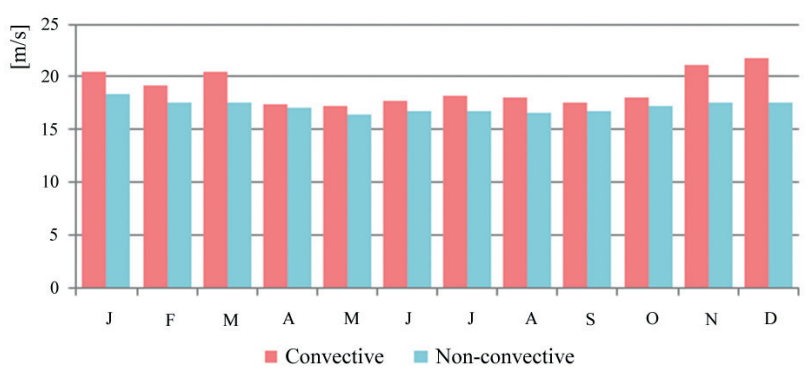

Fig. 6. Average convective and non-convective peak wind gusts during the days with a wind gust stronger than $15 \mathrm{~m} \mathrm{~s}^{-1}$

ber, while non-convective ones were observed in January (Fig. 6).

The comparison of the average annual number of thunderstorm days per meteorological station and thunderstorm days with wind gusts of more than $15 \mathrm{~m} \mathrm{~s}^{-1}$ is presented in Fig. 7. The analysis indicates that only around $15-20 \%$ of thunderstorms occurring from April to September generate a wind gusts stronger than $15 \mathrm{~ms}^{-1}$. On the other hand, this percentage significantly increases, to around $80 \%$, during winter months (from November to February), thus indicating that if any thunderstorm forms in these months, there is a higher probability that it may be capable of producing severe wind gusts.

A seasonal variability is also found when the recorded maxima of the peak gusts (in the timeframe of 2001-2015) are considered. The highest value in our database was $34 \mathrm{~m} \mathrm{~s}^{-1}$ recorded in Kraków on $8^{\text {th }}$ July 2015, within the occurrence of the severe thunderstorm. The highest value in a day without a thunderstorm was $33 \mathrm{~m} \mathrm{~s}^{-1}$, recorded

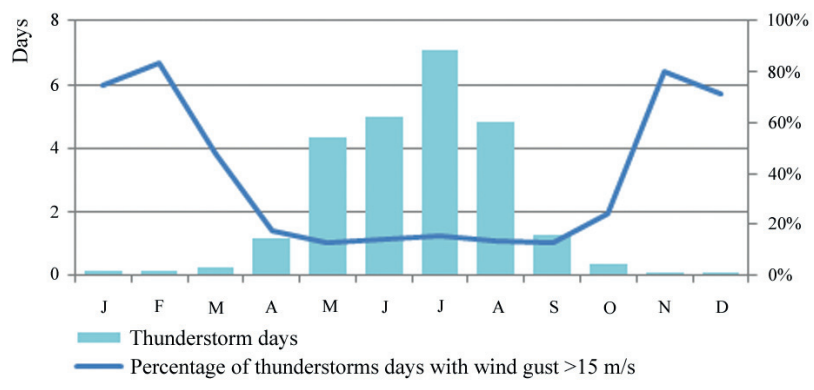

Fig. 7. Average annual number of thunderstorm days and the percentage of thunderstorm days producing wind gusts stronger than $15 \mathrm{~m} \mathrm{~s}^{-1}$; calculated as mean value for all analysed locations 
in Łódź on $31^{\text {st }}$ January 2002. All peak wind gust reports exceeding or equaling a value of $30 \mathrm{~m} \mathrm{~s}^{-1}$ are presented in Table 2. The most frequent exceedance of this threshold was observed at Łeba station and was due to non-convective mechanisms. This reason can be related to the close proximity of the Baltic Sea coastal zone, where nearsurface friction is smaller in comparison to the interior of Poland. Contrary to this, convective peak wind gusts over the land and exceeding or equalling $30 \mathrm{~m} \mathrm{~s}^{-1}$ were also reported in Kraków on $31^{\text {st }}$ July 2007 (32 $\left.\mathrm{m} \mathrm{s}^{-1}\right)$, in Poznań on $20^{\text {th }}$ June $2003\left(30 \mathrm{~m} \mathrm{~s}^{-1}\right)$ and in Warszawa on $29^{\text {th }}$ July $2005\left(30 \mathrm{~m} \mathrm{~s}^{-1}\right)$.

Table 2. Peak wind gust reports stronger or equal to $30 \mathrm{~m} \mathrm{~s}^{-1}$ (at 9 selected stations, in the period 2001-2015)

\begin{tabular}{|c|c|c|c|c|c|}
\hline \multirow{2}{*}{ No. } & \multirow{2}{*}{ Date } & \multicolumn{2}{|c|}{$\begin{array}{c}\text { Maximum wind } \\
\text { gust }\end{array}$} & \multirow{2}{*}{ Station } & Thunderstorm \\
\cline { 3 - 4 }$\left[\mathrm{m} \mathrm{s}^{-1}\right]$ & {$\left[\mathrm{km} \mathrm{h}^{-1}\right]$} & & \\
\hline 1. & $2015-07-08$ & 34 & 122.4 & Kraków & Yes \\
\hline 2. & $2002-01-31$ & 33 & 118.8 & Łódź & No \\
\hline 3. & $2002-01-29$ & 32 & 115.2 & Łeba & No \\
\hline 4. & $2013-12-06$ & 32 & 115.2 & Łeba & No \\
\hline 5. & $2002-01-29$ & 32 & 115.2 & Suwałki & No \\
\hline 6. & $2002-07-31$ & 32 & 115.2 & Kraków & Yes \\
\hline 7. & $2004-11-18$ & 31 & 111.6 & Łeba & Yes \\
\hline 8. & $2005-01-09$ & 31 & 111.6 & Łeba & No \\
\hline 9. & $2012-10-05$ & 31 & 111.6 & Łeba & No \\
\hline 10. & $2013-12-05$ & 31 & 111.6 & Łeba & No \\
\hline 11. & $2004-11-18$ & 31 & 111.6 & Suwałki & No \\
\hline 12. & $2004-03-21$ & 30 & 108 & Łeba & No \\
\hline 13. & $2005-01-08$ & 30 & 108 & Łeba & No \\
\hline 14. & $2006-12-31$ & 30 & 108 & Łeba & No \\
\hline 15. & $2015-01-11$ & 30 & 108 & Łeba & No \\
\hline 16. & $2003-06-20$ & 30 & 108 & Poznań & Yes \\
\hline 17. & $2005-07-29$ & 30 & 108 & Warszawa & Yes \\
\hline
\end{tabular}

In the monthly distribution the highest maximum peak wind gusts due to convection were recorded during the summer. Peak values over particular stations fell in July (average: $24.8 \mathrm{~m} \mathrm{~s}^{-1}$; Table 3), while the lowest were recorded in spring and autumn (April - $18.0 \mathrm{~m} \mathrm{~s}^{-1}$, September $-17.7 \mathrm{~m} \mathrm{~s}^{-1}$ ). A justification of this pattern may be related to the fact that in transitional months, thermodynamic instability is not large, while during the winter it is significantly supported by a dynamic airflow due to circulation patterns. Among the stations used in our analysis, the highest annual average of maximum peak gusts fell in Poznań $\left(22.8 \mathrm{~m} \mathrm{~s}^{-1}\right)$, while the lowest fell in Suwałki and Wrocław $\left(19.5 \mathrm{~m} \mathrm{~s}^{-1}\right)$.

Contrary to this, the monthly distribution of non-convective maximum peak wind gusts showed a clear maxi-
Table 3. Maximum monthly convective wind gusts $\left[\mathrm{m} \mathrm{s}^{-1}\right]$ in the period of 2001-2015; the lack of data indicates that no peak wind gusts exceeding or equal $15 \mathrm{~m} \mathrm{~s}^{-1}$ occurred

\begin{tabular}{|c|c|c|c|c|c|c|c|c|c|c|}
\hline Month & 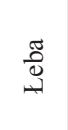 & 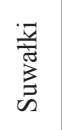 & $\begin{array}{l}\text { ज्ञ } \\
\text { N } \\
\text { N } \\
\text { n. }\end{array}$ & $\begin{array}{l}\text { 'స్ } \\
\text { สี้ } \\
\text { ¿ }\end{array}$ & 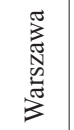 & $\begin{array}{l}3 \\
\frac{3}{0} \\
0 \\
5 \\
5\end{array}$ & 羿 & 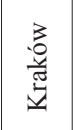 & 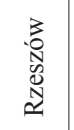 & $\stackrel{\infty}{\infty}^{\infty}$ \\
\hline Jan & 20 & - & 24 & - & 29 & 23 & 24 & 20 & 22 & 23.1 \\
\hline Feb & 17 & 19 & 21 & 23 & 24 & 19 & 21 & 20 & 16 & 20.0 \\
\hline Mar & - & 20 & 23 & 24 & 25 & 17 & 25 & 25 & 23 & 22.8 \\
\hline Apr & - & 20 & 20 & 19 & 17 & 16 & 17 & 19 & 22 & 18.8 \\
\hline May & 18 & 23 & 25 & 22 & 22 & 19 & 18 & 18 & 20 & 20.6 \\
\hline Jun & 23 & 20 & 29 & 30 & 22 & 19 & 23 & 23 & 22 & 23.4 \\
\hline Jul & 21 & 19 & 23 & 28 & 30 & 19 & 24 & 34 & 25 & 24.8 \\
\hline Aug & 24 & 20 & 22 & 26 & 22 & 24 & 15 & 23 & 23 & 22.1 \\
\hline Sep & 22 & 15 & 17 & 19 & 17 & 18 & 15 & 18 & 18 & 17.7 \\
\hline Oct & 24 & - & 18 & 17 & 18 & 22 & 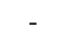 & 20 & 15 & 19.1 \\
\hline Nov & 31 & - & 23 & 23 & 18 & 22 & 20 & - & - & 22.8 \\
\hline Dec & 19 & - & 26 & 20 & 26 & 16 & 24 & - & 21 & 21.7 \\
\hline Avg. & 21.9 & 19.5 & 22.6 & 22.8 & 22.5 & 19.5 & 20.5 & 22.0 & 20.6 & 21.4 \\
\hline
\end{tabular}

mum during winter - in January (average: $28.7 \mathrm{~m} \mathrm{~s}^{-1}$ ), and in autumn - in October (average $26.6 \mathrm{~m} \mathrm{~s}^{-1}$; Table 4). The highest annual average peak values of non-convective wind gusts were recorded in Leba $\left(27.9 \mathrm{~m} \mathrm{~s}^{-1}\right)$, while at the other stations these values were significantly lower, with a minimum in Kraków $\left(22.2 \mathrm{~m} \mathrm{~s}^{-1}\right)$. This can be attributed to the fact that zonally circulating cyclones usually create the most dynamic weather patterns over the Baltic Sea and thus generate the highest peak gusts along the coast, while in the southern and eastern parts of the country, these are lower. By comparing an average of all maximum peak wind gusts in an annual course over particular stations due to convective and non-convective mechanisms, we can define that the non-convective (average $23.6 \mathrm{~m} \mathrm{~s}^{-1}$ ) are stronger than the convective ones $\left(21.0 \mathrm{~m} \mathrm{~s}^{-1}\right)$.

A more detailed distribution of the strongest wind gust at particular stations can be seen on the violin plots presented in Fig. 8 and 9. The results indicate that convective peak wind gusts were most frequently recorded in Szczecin and Warszawa, but the highest values on average fell in Łeba and Kraków. On the other hand, the most frequent peak wind gust reports with a strength of between 20 and $30 \mathrm{~m} \mathrm{~s}^{-1}$ were reported in Szczecin, Poznań and Warszawa.

In terms of non-convective peak wind gusts, these phenomena were most frequently observed in Łeba, where the number of cases, average value, and the number of cases with a strength of between 20 and $30 \mathrm{~m} \mathrm{~s}^{-1}$ were the highest. The second station in terms of number of cases was Szczecin (which also lies close to the coast), while the third were Suwałki and Rzeszów. The distribution of the data from the rest of the stations was very similar. 
Table 4. Maximum non-convective peak wind gusts $\left[\mathrm{m} \mathrm{s}^{-1}\right]$ measured at particular meteorological stations, and month within the period 2001-2015

\begin{tabular}{|c|c|c|c|c|c|c|c|c|c|c|}
\hline Month & 苞 & 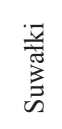 & 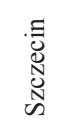 & $\begin{array}{l}\text { जี } \\
\text { స్ㅇ } \\
\text { م }\end{array}$ & 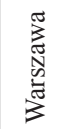 & 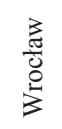 & 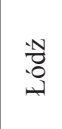 & 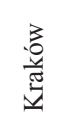 & 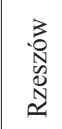 & $\stackrel{\infty 00}{\gtrless}$ \\
\hline Jan & 32 & 32 & 27 & 28 & 28 & 25 & 33 & 28 & 25 & 28.7 \\
\hline Feb & 29 & 24 & 23 & 28 & 22 & 21 & 21 & 20 & 24 & 23.4 \\
\hline Mar & 30 & 26 & 26 & 29 & 26 & 28 & 26 & 28 & 28 & 27.4 \\
\hline $\mathrm{Apr}$ & 27 & 24 & 26 & 24 & 24 & 25 & 24 & 25 & 24 & 24.8 \\
\hline May & 25 & 19 & 20 & 19 & 18 & 23 & 21 & 17 & 20 & 20.2 \\
\hline Jun & 26 & 20 & 19 & 19 & 19 & 21 & 17 & 18 & 17 & 19.6 \\
\hline Jul & 25 & 19 & 20 & 19 & 18 & 19 & 25 & 20 & 22 & 20.8 \\
\hline Aug & 25 & 24 & 19 & 19 & 22 & 18 & 22 & 17 & 21 & 20.8 \\
\hline Sep & 26 & 21 & 18 & 19 & 19 & 20 & 21 & 19 & 20 & 20.3 \\
\hline Oct & 31 & 24 & 27 & 26 & 29 & 24 & 24 & 26 & 28 & 26.6 \\
\hline No & 27 & 31 & 24 & 2 & 25 & 24 & 25 & 26 & 23 & 25.3 \\
\hline De & 32 & 22 & 26 & 28 & 22 & 24 & 25 & 22 & 24 & 25.0 \\
\hline Avg. & 27.9 & 23.8 & 22.9 & 23.4 & 22.7 & 22.7 & 23.7 & 22.2 & 23.0 & 23.6 \\
\hline
\end{tabular}

\section{Summary}

The occurrence of wind gusts are of great importance due to the possible destructive and hazardous effects to people and technical infrastructure that they may cause (Lorenc 1996, 2012; Ustrnul et al. 2014). However, there are not many studies for Poland touching on this issue, partly because of the hourly structure of SYNOP reports, where only part of the wind gusts that actually occur (Janiszewski 1988; WMO 2012) are included (i.e. usually without so called QNT records). This situation has partly been improved in recent years, but even in the official digital database of the IMGW-PIB this information has still only been collected from 2011 onwards. Other minor issues are related to the inconsistent measurement conditions at each single station (anemometer heights, obstacles, surface terrain roughness, etc.) or changes in measurement devices and their accuracy. Therefore, in this study the authors decided to use only 9 stations, which are quite evenly spaced over Polish territory and represent similar measuring conditions. Additionally, wind gust occurrence was analysed separately for the convective and non-convective generative types, which involve different mechanisms that shape the dynamics of these phenomena (Bradbury et al. 1994; Nakamura et al. 1996; Brasseur 2001; Jungo et al. 2002; Hofherr, Kunz 2010; Smith et al. 2012).

In this study we consider only wind gusts higher or equal to $15 \mathrm{~ms}^{-1}$, since they may be related to severe weather which could be destructive for people and the economy. The obtained results partially confirm the findings of Lorenc (1996, 2012), who stated that the highest

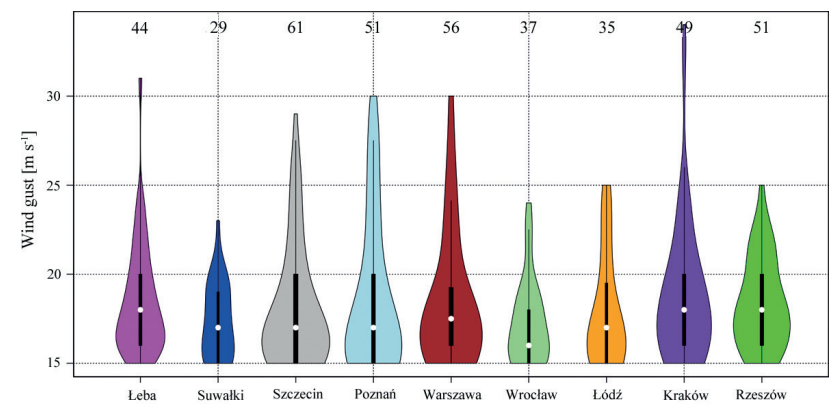

Fig. 8. A violin plot of convective peak wind gust database distribution at particular stations; numbers at the top and the thickness of the box denote the number of cases

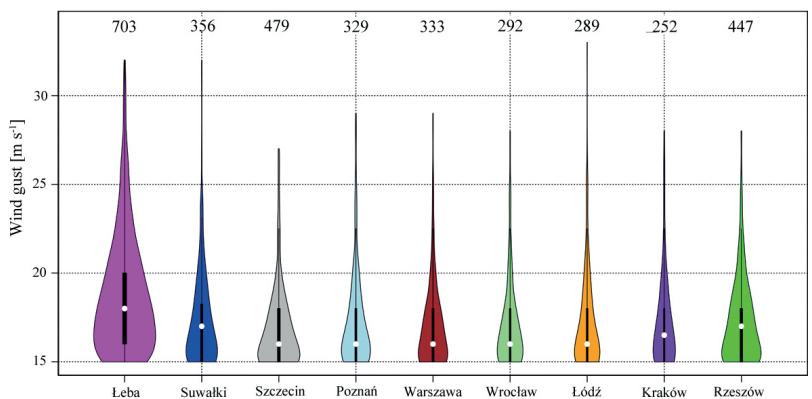

Fig. 9. A violin plot of non-convective peak wind gust database distribution at particular meteorological stations; numbers at the top and the thickness of the box denote the number of cases

frequency of convective wind gusts is usually observed in July, while the highest frequency for non-convective ones is typical for January. Despite this, the convective-related wind gusts during summer months are still not as frequent as the non-convective ones. However, it is worth mentioning that during the winter season convective related wind gusts accompanying cold fronts cause significantly stronger wind velocities when compared to non-convective situations (i.e. circulation-related only).

Convective wind gusts produce on average the highest values in July $\left(24.8 \mathrm{~m} \mathrm{~s}^{-1}\right)$, while the lowest values are typical for the transient months of spring and autumn (e.g. April $18.0 \mathrm{~m} \mathrm{~s}^{-1}$, September-October $17.7 \mathrm{~m} \mathrm{~s}^{-1}$ ). The strongest non-convective wind gusts occur in winter (max. Jan $28.7 \mathrm{~m} \mathrm{~s}^{-1}$ ) and the weakest are usually observed in the summer months (around $20 \mathrm{~m} \mathrm{~s}^{-1}$ ).

The most frequent exceedance of the considered threshold value of $15 \mathrm{~m} \mathrm{~s}^{-1}$ was found at Łeba station, and this was mostly due to non-convective mechanisms. This reason may be related to the proximity of the Baltic Sea, where near-surface friction is smaller than over the land, which causes the wind path propagation for prevailing westerlies to be more favourable.

The highest value of wind gust in the investigated period was found at base $34 \mathrm{~m} / \mathrm{s}$ and was recorded in Kraków on $8^{\text {th }}$ July 2015 within the occurrence of a severe thunderstorm. The highest value in a day without a thunderstorm was $33 \mathrm{~m} \mathrm{~s}^{-1}$, recorded in Łódź on $31^{\text {st }}$ January 2002, 
although 10 of 17 cases with wind gusts exceeding $30 \mathrm{~m} \mathrm{~s}^{-1}$ were found at Łeba station. The most frequent convective wind gusts between 20 and $30 \mathrm{~m} \mathrm{~s}^{-1}$ were reported in Szczecin, Poznań and Warszawa.

\section{Bibliography}

Bielec-Bąkowska, Z., 2003, Long-term variability of thunderstorm occurrence in Poland in the $20^{\text {th }}$ century, Atmospheric Research, 67-68, 35-52, DOI: 10.1016/S0169-8095(03)00082-6

Bradbury W.M.S., Deaves D.M., Hunt J.C.R., Kershaw R., Nakamura K., Hardman M.E., Bearman P.W., 1994, The importance of convective gusts, Meteorological Applications, 1 (4), 365-378, DOI: 10.1002/met.5060010407

Brasseur O., 2001, Development and application of a physical approach to estimating wind gust, Monthly Weather Review, 129 (1), 2-25, DOI: 10.1175/1520-0493(2001)129<0005:DAAOA $\mathrm{P}>2.0 . \mathrm{CO} ; 2$

Czernecki B., Taszarek M., Kolendowicz L., Konarski J., 2016, Relationship between human observations of thunderstorms and PERUN lightning detection network in Poland, Atmospheric Research, 167, 118-128, DOI: 10.1016/j.atmosres.2015.08.003

Hofherr T., Kunz M., 2010, Extreme wind climatology of winter storms in Germany, Climat Research, 41 (2), 105-123, DOI: $10.3354 / \mathrm{cr} 00844$

Janiszewski F., 1988, Instruction for meteorological stations, (in Polish), Wydawnictwa Geologiczne, Warszawa, 264 pp.

Jungo P., Goyette S., Beniston M., 2002, Daily wind gust speed probabilities over Switzerland according to three types of synoptic circulation, International Journal of Climatology, 22 (4), 485-499, DOI: 10.1002/joc.741

Kolendowicz L., 2006, The influence of synoptic situations on the occurrence of days with thunderstorms during a year in the territory of Poland, International Journal of Climatology, 26 (13), 1803-1820, DOI: $10.1002 /$ joc. 1348

Lorenc H., 1996, The structure and energy resources of wind in Poland, (in Polish), Materiały Badawcze IMGW. Seria: Meteorologia, 25, $155 \mathrm{pp}$.

Lorenc H., 2012, Maximum wind speed in Poland, (in Polish), IMGW-PIB, Warszawa, $100 \mathrm{pp}$.

Nakamura K., Kershaw R., Gait N., 1996, Prediction of nearsurface gusts generated by deep convection, Meteorological Applications, 3 (2), 157-167, DOI: 10.1002/met.5060030206

Niedźwiedź T. (ed.), 2003, Meteorological glossary, (in Polish), IMGW, Polskie Towarzystwo Geofizyczne, Warszawa, 496 pp.

Smith B.T., Thompson R.L., Grams J.S., Broyles C., Brooks H.E., 2012, Convective modes for significant severe thunderstorms in the contiguous United States. Part I: Storm classification and climatology, Weather and Forecasting, 27 (5), 1114-1135, DOI: 10.1175/WAF-D-11-00115.1

Taszarek M., Czernecki B., Kozioł A., 2015, A cloud-to-ground lightning climatology for Poland, Monthly Weather Review, 143, 4285-4304, DOI: 10.1175/MWR-D-15-0206.1

Ustrnul Z., Wypych A., Henek E., Czerkierda D., Walawender J., Kubacka D., Pyrc R., Czernecki B., 2014, Meteorological hazard atlas of Poland, Wydawnictwo Attyka, Kraków, 162 pp.

Ustrnul Z., 1992, Potential conditions of foehn wind occurrence in the Polish part of Carpathian Mountains, (in Polish), Zeszyty Naukowe UJ, Prace Geograficzne, 90, 97-112

WMO, 2010, Measurements of surface wind, [in:] Guide to meteorological instruments and methods of observation, World Meteorological Organization, WMO-No. 8, Genewa, I.5 1-11

Żurański J.A., Jaśpińska B., 1996, Directional analysis of extreme wind speeds in Poland, Journal of Wind Engineering and Industrial Aerodynamics, 65 (1-3), 13-20, DOI: 10.1016/S01676105(97)00018-4 